Contents lists available at http://ejournal.uin-suska.ac.id

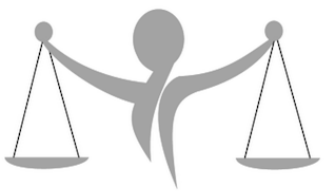

Al-Ittizaan: Jurnal Bimbingan Konseling Islam

ISSN: $2723-021 \mathrm{X}$

Journal homepage: http://ejournal.uin-suska.ac.id/index.php/alittizaan

\title{
DAMPAK KOREA WAVE TERHADAP PRILAKU REMAJA DI ERA GLOBALISASI
}

\author{
Lisa Anggraini Putri ${ }^{1}$ \\ ${ }^{1}$ Universitas Islam Negeri Sultan Syarif Kasim Riau
}

\begin{tabular}{|c|c|}
\hline Article Info & ABSTRACT \\
\hline Article history: & $\begin{array}{l}\text { Along with the development of technology in this globalization era, it is } \\
\text { very easy for humans to obtain information, one of which is by accessing }\end{array}$ \\
\hline Received Mart $12^{\text {th }}, 2020$ & the development of kpop world. The more easy it is to get this information, \\
\hline Revised April 20 $0^{\text {th }}, 2020$ & causing teenagers to become fanatical about what they are idolizing. As a \\
\hline Accepted April $26^{\text {th }}, 2020$ & result of the teenage fanatics causes several positive and negative impacts \\
\hline Keyword: & $\begin{array}{l}\text { social media. The increase in the development of this newspaper wave is } \\
\text { very necessary to be discussed and must be considered by parents in seeing }\end{array}$ \\
\hline K-pop, & the development of their children. In this journal the author discusses the \\
\hline Fanatik, & positive and negative effects of this kpop development. Data taken by the \\
\hline Remaja & $\begin{array}{l}\text { this and reduce adolescent fanaticism towards kpop, the writer shares the } \\
\text { ways that parents need to do. }\end{array}$ \\
\hline
\end{tabular}

\begin{abstract}
ABSTRAK
Seiring dengan berkembangnya teknologi pada era globalisasi ini sangat memudahkan bagi manusia untuk memperoleh informasi salah satunya denagan akses perkembangan dunia kpop. Semakin mudahnya mendapatkan informasi tersebut menyebabkan para remaja menjadi fanatik terhadap yang mereka idolakan tersebut.akibat dari fanatik remaja tersebut menyebabkan bebrapa dampak baik positif maupun negative terhadap dia. Penyebabnya dari serial drama, music, fashion, kosmetik, budaya, media social. Peningkatan dari perkembangan Koran wave ini sangat perlu untuk dibahas dan harus diperhatikan oleh orang tua dalam melihat perkembangan anaknya.pada jurnal ini penulis membahas tentang dampak positif dan negative dari perkembangan kpop ini. Data yang diambil oleh penulis didapatkan dari buku, jurnal, internet, Koran. Untuk menyikapi hal tersebut dan mengurangi fanatisme remaja terhadap kpop penulis membagikan cara yang perlu dilakukan oleh orang tua.
\end{abstract}

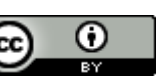

(C) 2020 The Authors. Published by UIN Sultan Syarif Kasim Riau.

This is an open access article under the CC BY license

(https://creativecommons.org/licenses/by/4.0)

\section{Corresponding Author:}

\section{Lisa Anggraini Putri}

Universitas Islam Negeri Sultan Syarif Kasim Riau

Email: lisaanggrainiputri25@gmail.com 


\section{Pendahuluan}

Globalisasi sebuah factor pendukung dari munculnya korea wave. Menurut (Sara M.Hamilton,2008) menyebutkan bahwa gloalisasi diartikan sebagai integrasi perekomian, budaya, politik, aspek social, dan perkembangan teknologi yang sangat maju sehinnga memudahkan bagi masyarakat untuk mengetahui barbagai informasi. Salah satu aspek yang paling mempengaruhi yaitu aspek budaya suatu negara dengan negara lainnya. Salah satu budaya yang sedang berkembang di Indonesia saat ini adalah budaya pop Korea atau yang sering kita dengar dengan istilah Korean wave.

Korean wave atau hallyu adalah sebuah istilah yang diberikan pada budaya korea pop atau gelombang korea. Gelombang korea ini sudah mempengaruhi berbagai belahan dunia tak terkecuali di Indonesia. Di Indonesia fenomena gelombang korea sangat berpengaruhi terutama bagi anak muda atau remaja. Pada umumnya remaja tersebut sangat menyenangi tayangan drama korea atau yang disebut drakor. Disamping tanyangan drama yang berhasil membuat remaja menyukainnya ada juga beberapa factor lain seperti music dimana yang merajalela saat ini dengan ketampanan dari anggota boyband dan girlband serta music yang membuat semangat untuk memulai hari-hari bagi kita. Factor lainnya yang membuat remaja menyeukai kpop dari fashion yang seperti baju, kosmetik, dan apa yang dipakai oleh idol mereka (Nastiti, 2010).

Popularitas budaya Korea telah memberikan citra positif bagi konstruksi Asianization di seluruh dunia. Globalization dipahami sebagai hasil dariperjalanan modernitas dunia. Awal muncul korea di Indonesia pada tahun 2000 melalui tayangan drama "Endless Love". Dimana pada saat drama tersebut ditanyangkan banyak remaja dan masyarakat menyukainnya karena jalan cerita yang membuat penonton hanyut kedalam drama tersebut dan disungguhkan oleh kisah romantis dan didukung oleh actor dan aktris yang ganteng dan cantik, setelah tanyangan drama korea perlahanlahan menampakkan dirinya diindonesia melalui music, fashion yang sangat disukai oleh remaja (Giddens 1991 dalam Doboo Shim 2011).

Kepopuleran kpop diindonesia menyebabkan kekerasan simbolik dimana kekerasan simbolik adalah kekerasan dalam bentuknya yang halus, kekerasan yang dikenakan pada agen-agen sosial tanpa mengundang resistensi. Sehingga menyebabkan remaja atau generasi muda lebih tertarik pada kpop dibandingkan Negara sendiri. Banyak dampak pengaruh yang disebabkan oleh kpop terhadap kaum remaja baik itu positif dan negative. Untuk menyikapi hal tersebut sangat diperlukan perhatian orang tua (Bourdieu,1991).

Penulisan jurnal ini bertujuan untuk membahas mengenai bagaimana pengaruh yang ditimbulkan oleh perkembangan kpop di era globalisasi.

\section{Metode}

Tipe penelitian yang digunakan dalam penelitian ini adalah tipe Deskriptif Analitik, dimana penulis memberikan penjelasan secara konkrit mengenai dampak korea wave terhadap remaja pada era globalisasi ini. Jenis data yang penulis gunakan dalam penelitian ini adalah data sekunder, yaitu data yang diperoleh dari buku-buku, koran, internet dan sebagainya yang berkaitan dengan masalah yang diteliti.

\section{Hasil dan Pembahasan}

Pada era globalisasi yang memiliki berbagai teknologi yang maju dan berkembang pesatsabgat mudah sekali dalam mendapatkan berbagai informasi baik melalui audio maupun visual. Globalisasi sering kali dikaitkan dengan bagaimana cara dan upaya strategi dari Negara barat untuk memperluaskan berbgai produknya. Kekuatan terbesar Negara barat dalam menembangkan konsep globalisasinya. Gejala baru yang timbul pada saat era globalisasi dimana dulunya di dominasi oleh Negara barat (Hollywood) sekarang muncul perkembangan budaya korea wave sebagai fenomena dari asia yang sangan booming di berbagai belahan dunia dalam beberapa tahun terakhir ini (Eun dan Jiwon, 2007:124). 
Seiring dengan meningkatnya popularitas Korea wave di dunia internasional sangat mempengaruhi kehidupan masyarakat di dunia Internasional. Pengaruh korea wave di dunia internasional tak terkecuali juga di Indonesia. 'Korean Wave' atau 'Hallyu' yang sekarang sangat berpengaruh di Indonesia terutama dikalangan remaja (Wijayanti, 2012).

Pesatnya perkembangan budaya korea secara meluas dan diterima public dunia. DEman budaya juga dikenal dengan istilah Korean Wave. Hallyu atau Korean Wave adalah sebuah istilah yang diberikan untuk tersebarnnya budaya pop korea atau diartikan juga dengan gelombang korea secara global di berbagai Negara di dunia atau secara singkatnya perkembangan globalisasi budaya Korea. Di Indonesia khususnya dikalangan muda atau remaja umumnya sangat menyukai serial drama korea, music korea kpop, fashion yang dipakai oleh mereka (Nastiti, 2010).

Hal ini sangat berbeda sekali pada saat tahun 1990 dimana perkembangan budaya hanya didominasi oleh Negara barat seperti Amerika. Tapi semejak awal tahun 2002 negara-negara asia mulai menjadi fenomena baru sebagai budaya yang pupuler. Sehingga budaya popular sekarang sangat didominasi oleh Negara asia terutama Korea Selatan sebagai budaya yang popular di dunia saat ini. Di Indonesia titik awal munculnya kpop mulai pada pertengahan 2002. Beberapa waktu setelah piala dunia tahun 2002 yang diadakan di korea selatan dan juga disiarkan melalui stasiun swasta tanah air. Setelah munculnya korea selatan di tv Indonesia membuat masyarakat jadi penasaran tentang budaya mereka. Setelah itu bermunculah tayangan drama korea di tv Indonesia seperti drama Full House, Winter Sonata, Princess Hours. Dimana drama tersebut merupakan awal muncul drama korea di Indonesia. Drama tersebut sangat mempengaruhi masyarakat Indonesia. Karena menampilkan kisah yang romantic dan jalur cerita yang membuat siapa yang menontonnya ikut hanyut dalam cerita. Selain itu disungguhkan dengan actor dan aktris yang ganteng, kualitas acting yang bagus beserta ost dramanya yang bagus (Suryanti, 2016).

Bentuk dari kepopuleran korea Ini snagat beragam bentuknya mulai dari drama, film, fashion, music, maupun tempat wisata (Ardia, 2014). Penyebarluasan korea wave secara global disebut dengan K-pop dalam bahasa koreanya Hallayu. Penayangan drama korea berbasiskan pada historitis, life, dan romantisme sehingga cocok dikomsumsi oleh penonton dari bebagai lapisan manapun (Dirujuk dari buku Choi Cheonosa (2011).

Pengaruh dari drama korea ini mempunyai daya jual yang bagus untuk di ekspor ke Negara lain, terutama di Negara asia yang berhubungan dekat dengan Korea Selatan . keseimbangan drama korea dan music dari ost dramanya membuat orang tertarik juga dengan music korea (k-pop) untuk diminati. Terutama perpaduan antara jalan cerita dan music sebagai latar dari serial tersebut, membuat para penonton hanyut kedalam drama tersebut. Dari tanyangan drama tersebutlah music kpop makin merambah di Indonesia. Penampilan dan fisik dari para artis korea inilah yang membuat para penggemar mengidolakannya dan histeris terhadapnya. Music korea didominasi oleh boyband, girlband, dan solois. Pada umumnya boyband dan girlband korea memiliki banyak jumlah personil sehingga para pemnggemar mempunyai bias dalam sebuah gup tersebut. Dalam band tersebut mempunyai dance yang kompak dan dipadukan konsep music klip yang bagus. Meluasnya Korean Wave disertai oleh peningkatan komsumsi industri fashion. Produk fashion yang sangat diminati laris manis dipasaran internasional yang meliputi dua macam yaitu industri konveksi dan industri kecantikan (Marpaung, A. 2014).

Dengan berbagai faktor penyebaran Korea Wave mengakibatkan terkususnya pada anak muda lebih tertarik dan mengaung-agungkan kpop dibandingkan Negara sendiri. Dan dari sinilah terdapat berbagai pengaruh negative atau positif kepada remaja saat ini.

Factor positif yang bisa diambil dari perkembangan kpop yang pesat ini diantaranya adalah:

1. Kpop Menjadi Inspirasi di Dunia Fashion

Banyaknya anak muda yang mempunyai kamauan besar untuk mengetahui hal-hal yang berbau korea sehingga menyebabkan mereka terisnpirasi untuk mencontoh atau meniru cara berpakaian, cara mengetahui perpaduan mode dari idol yang mereka kagumi .

2. Mengetahui Citra Dirinya 
Citra diri adalah gambaran yang dimiliki seseorang terhadap dirinya sendiri sebagai ciptaan yang memilik fisik yang dikaitkan dengan karakteristik fisik dalam penampilan seseorang tersebut secara umum atau pemikiran seesorang tentang pandangan orang lain terhadap dirinya dan bagaiman orang menilai dirinya (Wibowo, 2007).

3. Dapat Bersosialisasi Dan Mandiri

Dengan adanya dunia kpop ini sehingga remaja dapat lebih kreatif dalam mengembangkan dirinya. Dengan adanya hubungan pertemanan, mereka menjadi memiliki banyak teman dari berbagai daerah, atau pun dari Negara luar karea sesama penggemar idol yang dikagumi Seperti belajar mendiri dengan berani berusa seperti membuka online shop dengan menjual hal-hal berbau kpop seperti pakaian, kosmetik, dan lainnya, dengan keuntungan dari penjualan online bisa membuat seseorang jadi mandiri. Dikatakan dapat bersosialisasi karena dengan mereka yang memiliki sifat yang sama, mengagumi idola yang sama, menyukai drama yang sama sehingga terjalin suatu hubungan yang cepat berlandasakan sesame fans kpop (Hurlock,2003).

4. Dapat Memotivasi dan Semangat

Dapat memotivasi karena dengan mengagumi hal yang berbau korea mereka akan otomatis ingin belajar memahami bahasa korea tersebut sehingga dapat memperluas tambahan bidang kuasa bahasa asing. Dan juga music dapat juga dijadikan motivasi karena dapat menambah semangat belajar dengan mendengarkan music kpop tersebut. Dan juga kisah idola mereka juga dianggap menginspirasi yang mereka tuangkan lewat lagu-lagu ciptaannya.

5. Manfaat secara emosional dapat membuat senang, menghilangkan stress bagi remaja yang lelah dari pekerjaa rumah atau tuga sdari sekolah.

Disamping adanya dampak positif tentu juga ada dampak negative yang disebabkan oleh pengaruh kpop tersebut seperti:

1. Sikap fans yang berlebihan

2. Terjadi fanatisme terhadap remaja tersebut

Fanatisme sangat fenomena pada zaman modern ini, realitas pribadi social dari masyarakat, karena pada saat ini berpengaruh pada seorang individu sehingga menciptakan kepercayaan dan pemahaman berupa pengabdian, hubungan, kesetiaan, kecintaan (Seregina, Koivisto \& Mattila, 2011).

Fanatisme diartikan pengabdian seseorang terhadap suatu objek dimana menimbulkan gairah, keintiman, dan hasrat yang biasanya melampaui rata-rata dari biasanya. Objek biasanya mengacu pada produk, merek, serta seseorang (selebriti), acara tv, dan kegiatan konsumsi lainnya. Fanatisme biasanya menganggap dirinya benar dan mengabaikan fakta dan argument dari yang bertentangan dengan pemikiran dan pemahaman mereka (Chung, Beverland, Farrelly \& Quester, 2008).

Jika dilihat dan dipelajari fanatisme selalu sebagai berkelompok, banyak dari mereka para penggemar. Penelitian yang dilakukan Seregina, Koivisto dan Mattila (2011) adalah mengetahui Unsur aspek yang hadir sampai batas tertentu dalam semua fanatisme. Tematema komunalitas fanatisme ini dibahas lebih lanjut di bawah ini sebagai berikut:

a. Menjadi penggemar untuk orang lain

Dapat dilihat dan digambarkan seseorang yang menjadi penggemar orang lain yang biasanya memiliki sebuah kelompok dan memiliki tujuan untuk mendapatkan temanteman serta aktif dalam berkomunikasikan nilai-nilai dan identitas orang lain. Biasanya memiliki grup chat untuk saling berbagi informasi.

b. Menjadi Pengemmar untuk diri sendiri 
Seseorang yang menjadi fans seorang diri dengan membeli berbagai atribut dan koleksi tanpa adanya paksaan dari orang lain.

3. Timbul sikap peneriun terhadap citra diri yang berlebihan

Pengaruh dari tayangan drama korea yang menarik perhatian public terutama remaja sehingga menimbulkan pengimitasian. Hal ini dibuktikan dengan adanya gaya hidup dan mengoleksi hal yang berbau K-pop, serta dalam peniruan penampilan fisik dari citra hidup dirinya (Kaparang, 2013). Dengan peniruan ini sehingga remaja tersebut akan meniru sedemikian mungkin khususnya bagi perempuan. Mereka akan mengikuti fashion dengan menggunakan baju yang kurang layak untuk dipakai. Bertentangan sekali dengan negra kita yang sebagian besar mengenut agama islam (Tartila,2013).

4. Konformitas

Konformitas yaitu suatu prilaku tertentu yang dilakukan karena pengaruh orang lain atau kelompoknya untuk melakukan prilaku dan tindakan yang sama. Maka individu tersebut melakukannya baik menyukainnya atau tidak menyukai apa yang dia lakukan yang sedang terjadi (Sears, Freedman, \& Peplau, 1994).

Konformitas tidak hanya pada prilaku dan tindakan yang dipengaruhi orang lain tetapi individu itu juga bertindak dan berpikir secara berbeda dari apa yang dilakukannya jika seorang diri (Myers, 2012).

5. Membuang waktu dan uang untuk hal yang sia-sia

Terkadang remaja sekarang ini kadang lupa akan waktu yang telah terbuang karana terlena akan keinginan melihat idolanya sehingga menyebabkan lupa belajar, lupa istirahat gara-gara nonton drama korea, dan membuang uang karena membeli hal-hal yang tidak berguna dan kadang cenderung membeli kuota internet yang berlebihan hanya untuk menstalking idolanya.

Kiat yang bisa dilakukan oleh orang tua antara adalah dengan cara membatasi dan mengontrol anak tersebut jika sudah terlalu fanatic sekali terhadap idolanya dengan mengalihkan dengan mungkin membawa anak tersebut pergi liburan, mengadakan family time, membawa kepengajian.

6. Kesehatan mata karena sering kali melihan ponsel.

7. Insomnia atau kesulitan tidur karena sudah terlalu sering bergadang hanya untuk meraton menonton drama yang disukai. Hal ini tentu sangat menyita waktu istirahat sseorang individu tersebut.

8. Kadang efek dari budaya kpop ini juga mempengaruhi anak dalam berpakain terutama untuk perempuan yang ingin mencontoh apa pakaian yang dipakai oleh idolanya. Kadang mereka memakai baju yang sangat tidak sopan dan ini bertentangan sekali dengan agama apalagi Indonesia yang didominasi oleh agama islam.untuk itu perlu perhatian dari orang tua untuk mengawasi dan mengontrol anaknya.

\section{Kesimpulan}

Korean Wave adalah sebuah istilah yang diberikan untuk tersebarnya budaya Pop Korea atau gelombang Korea secara global di berbagai negara di dunia tidak terkecuali di negara Indonesia, atau secara singkat terpusat pada perkembangan globalisasi budaya Korea. Di Indonesia saat ini, fenomena golombang Korea melanda generasi muda terutama remaja Indonesia yang umumnya menyenangi drama atau disebut K-Drama dan Musik Pop korea atau yang lebih dikenal dengan K-Pop. Dampak yang disebabkan oleh perkembangan kpop ini diantaranya ada positif da nada negative. Dampak positif diantaranya adalah dapat menjadi inspirasi fashion, cara berpakaian, dan dapat membuat orang tersebut mandiri dengan menjual barang-barang yang berbau kpop yang akan pasti diburu oleh fans kpop. Disamping dampak positif tentu juga ada dampak negatifnya diantaranya adalah timbul sikap fanatisme terhadap idola, fansing dengan membelikan idola barang-barang mahal, dan juga dampak yang paling berpengaruh adalah menggunakan baju tak layak dipakai bagi perempuan yang 
bertentangan apalagi dalam agama islam. Disini saya menyarankan kepada orang tua selalu mengawasi anaknya dan mengontrol jika sudah terlalu berlebihan dalam menggemari kpop. Bisa menggunakan cara mengalihkan dengan mungkin membawa anak tersebut pergi liburan, mengadakan family time, membawa kepengajian.

\section{Daftar Pustaka}

Ardia, V. (2014). Drama korea dan Budaya Popular. Jurnal Komunikasi, 2(3), 12-18.

Bourdieu, Pieree. 1991, Language and Symbolic Power. Cabridge: Harvard

Chung, E., Beverland, M., Farrelly, F., \& Quester, P. (2008). Exploring consumer fanaticism: Extraordinary devotion in the consumption context. Journal of Advances in Consumer Research. 35 (4), 333-340.

Hamilton, Sara M. (2009). Globalization. Minnesota: Abdo Consulting Group

Hurlock, Elizabeth B. 2003. Psikologi Perkembangan. Jakarta : Erlangga.

Kaparang, M. Olivia. 2013. Analisa Gaya Hidup Remaja Dalam Mengimitasi Budaya Pop Korea Melalui Televisi.Jurnal Acta Diurna Vol. II/No. 2/ 2013.Diakses pada tanggal 28 Februari 2016 darihttp://ejournal.unsrat.ac.id/index.php/actadriuna/article/viewFile/1138/916.

Kim, Eun Mee dan Jiwon Ryoo. "South Korean Culture Goes Global: KPop and the Korean Wave" diakses melalui http://kossrec.org/ board/imgfile/KSSJ Vol.34. no.1(Eun Mee Kim\&Jiwon Ryoo)). Pdf. Diakses pada 16 November 2013 pukul 11.50 WIB.

Marpaung, A. 2014. Tren K-pop yangbombastis.http://www.siperubahan.com/read/254/Tren-KPOP-yangBombastis. Diakses pa-da tanggal 31 agustus 2015.

Myers, D. G. (2012). Psikologi Sosial (Social Psychology) Jilid 1 Edisi Kesepuluh. Jakarta: Salemba Humanika

Nastiti, A. D. (2010). "Korean Wave" di Indonesia: Antara Budaya Pop, Internet, dan Fanatisme Pada Remaja (Studi Kasus Terhadap Situs Assian Fans Club Di Indonesia Dalam Perspektif Komunikasi Antar Budaya). Journal of Communication. 1 (1), 1-23.

Sears, D. O., Freedman, J. L., \& Peplau, L. A. (1994). Psikologi sosial jilid 2 (terjemahan Michael Adriyanto). Jakarta: Penerbit Erlangga.

Seregina, A., Koivisto, E., \& Mattila, P. (2011). Fanaticism- Its Developmentand Meanings in Consumers Lives. Journal of Aalto University School of Economics. 1 (1), 1-106.

Suryanti, D. (2016). Kekerasan Simbol Suryanti, D. (2016). Kekerasan Simbolik Tayangan Drama Seri Korea Terhadap Perilaku Remaja Asrama Putri Kabupaten. EJournal Sosiatri-Sosiologi, 4(2), 197-211.ik Tayangan Drama Seri Korea Terhadap Perilaku Remaja Asrama Putri Kabupaten. EJournal Sosiatri-Sosiologi, 4(2), 197-211

Tartila, P. L. (2013). Fanatisme fans kpop dalam blog netizenbuzz. Commonline, 2(3), 190-205.

Retrieved from http://airde.multiply.com

University Press. 
Wibowo, H. 2007. Fortune Favors The Ready. Bandung: OASE Mata Air Makna. Diakses pada tanggal 20 Februari 2016 darihttps://

books.google.co.id/books?id=5IBKzqYvPfsC\&pg=PA82\&dq=citra+diri\&hl=id\&sa=X\&redir esc $=\mathrm{y} \# \mathrm{v}=$ onepage $\& \mathrm{q}=\mathrm{citra} \% 20 \mathrm{diri} \& \mathrm{f}=$ false .

Wijayanti, A. A. (2012). Hallyu: Youngstres Fanaticism of Korean Pop Culture (Study of Hallyu Fans Yogyakarta City). Journal of Sociology. 3 (3), 1-24. 